\title{
Down-Regulation of HLA-A Expression Correlates with a Better Prognosis in Colorectal Cancer Patients
}

\author{
Anand G. Menon, Hans Morreau, Rob A.E.M. Tollenaar, E. Alphenaar, \\ Marjo van Puijenbroek, Hein Putter, Connie M. Janssen-van Rhijn, \\ Cornelis J.H. van de Velde, Gert Jan Fleuren, and Peter J.K. Kuppen
}

Department of Surgery (AGM, RAEMT, EA, CMJ-VR, CJHVV, PJKK), Department of Pathology (AGM, HM, EA, MVP, GJF), and Department of Medical Statistics (HP), Leiden University Medical Center, Leiden, The Netherlands

\begin{abstract}
SUMMARY: To evaluate the prognostic impact of human leukocyte antigen class I (HLA-I) expression on immune surveillance in colorectal cancer, we studied 88 curatively resected tumors for HLA-A and HLA-B/C expression and correlated these data to clinical and histopathological parameters. HLA-A was normal (all tumor cells had HLA expression) in 32\%, reduced (HLA-negative and -positive tumor cells coexisted) in $56 \%$, or absent (no tumor cells expressed HLA) in $12 \%$ of evaluable cases. HLA-B/C was normal in $47 \%$, reduced in $47 \%$, and absent in $7 \%$ of the cases. Considering both markers, total HLA-I expression was normal in $27 \%$, reduced in $63 \%$, absent in $7 \%$, and could not be evaluated in $3 \%$ of the cases due to absent HLA-A expression in tumor and normal cells. Down-regulation of HLA-A expression significantly correlated with a lower tumor stage $(p=0.005)$, mucinous tumors $(p=0.05)$, a lower incidence of recurrences $(p=0.03)$, and a longer disease-free survival $(p=0.02)$. Down-regulation of HLA-B/C expression correlated with a lower tumor stage $(p<0.001)$ and a longer disease-free survival $(p=0.04)$. In multivariate analysis, HLA-A down-regulation was the only prognostic factor correlated with a longer disease-free survival $(p=$ 0.02). Six tumors were negative for HLA-A and $-B / C$ and did not recur during follow-up. Therefore, we analyzed microsatellite instability (MSI) in these cases. Three of these six tumors indeed showed down-regulation of MLH-1, MSH-2, or MSH-6, indicating a MSI-high phenotype. Beta-2-microglobulin protein expression was lost in five of six of the HLA-I-negative cases, but frame shift mutations in three repetitive sequences in $\beta 2$-microglobulin were absent. In contrast, loss of $\mathrm{MLH}-1, \mathrm{MSH}-2$, and MSH-6-protein expression was only observed in two of nine matched controls with reduced or normal HLA-A and -B/C expression. Our data showed that HLA-I was down-regulated in $72 \%$ of colorectal cancers and provided independent prognostic information for a longer disease-free survival. The better prognosis may be caused by elimination of HLA-negative cells by natural killer cells or by an attenuated tumor aggressiveness, as is seen in tumors with a MSI-high phenotype. (Lab Invest 2002, 82:17251733).
\end{abstract}

$C$ olorectal cancer is among the most common malignancies in men and women in the Western world (Greenlee et al, 2000). Hematogenous and lymphatic micrometastases occur early during carcinogenesis in a large proportion of patients. Once distant metastases are detected, the available treatment options are scarce and potentially toxic and the prognosis is poor. Other treatment modalities, such as immunotherapy, are getting more attention (Bremers and Parmiani, 1999).

It is generally accepted that an antitumor reaction is primarily mediated by cytotoxic T-lymphocytes. This process requires the presence of human leukocyte antigen class I molecules (HLA-I) on the (pre)neoplastic target cell (Bernards et al, 1983; Wallich et al, 1985). HLA-I is a complex molecule, consisting of a heavy chain (encoded by the HLA-A, -B, and -C loci on chromosome 6) and a light chain (encoded by $\beta 2$

\section{DOI: 10.1097/01.LAB.0000043124.75633.ED}

Received August 13, 2002.

Address reprint requests to: Dr. P. J. K. Kuppen, Leiden University Medical Center, Department of Surgery, K6-R, P.O. Box 9600, 2300 RC Leiden, The Netherlands. E-mail: P.J.K.Kuppen@lumc.nl microglobulin ( $\beta 2 \mathrm{~m})$ on chromosome 15$)$, which together with a peptide and costimulatory molecules are presented to cytotoxic $T$ lymphocytes. Tumor cells harbor many genetic defects, potentially leading to the production of altered proteins that can be targets for the immune system. This holds especially true for tumors with the "mutator phenotype," which are characterized by defects in the mismatch repair genes. However, tumors can down-regulate HLA-I expression and thereby evade cytotoxic $T$ lymphocytemediated elimination. Down-regulation of HLA-I has been reported in a variety of malignancies (Esteban et al, 1996), including a significant percentage of colorectal cancers and its precursor adenomas (Cordon et al, 1991; Garrido et al, 1993; Lopez-Nevot et al, 1989; Moller et al, 1991b; Momburg et al, 1986; Tsioulias et al, 1993) and may result in a worse clinical outcome. This correlation has indeed been observed in a number of malignancies, such as breast cancer (Concha et al, 1991), melanoma (van Duinen et al, 1988), and laryngeal carcinoma (Esteban et al, 1996) but not for colorectal cancer (Cordon et al, 1991; Lopez-Nevot et al, 1989; Moller et al, 1991b; Momburg et al, 1986; Stein et al, 1988). Immunohistochemical studies on HLA-I expression in (colorectal) cancer most com- 
monly investigated the expression of the entire HLA$\mathrm{ABC} / \beta 2 \mathrm{~m}$ complex using the antibody $\mathrm{W} 6 / 32$. W6/32 recognizes the nonpolymorphic residues of the HLA-I molecule and therefore might underscore subtle changes in the polymorphic areas (Barnstable et al, 1978). We investigated HLA-A and HLA-B/C expression separately in curatively resected colorectal cancer patients using two monoclonal antibodies, HCA2 and HC-10 (Stam et al, 1990). In this report, we present the frequency of these locus-specific alterations in curatively resected colorectal cancer patients and their correlation with clinical and histopathological parameters and prognosis.

\section{Results}

\section{Frequency of HLA-A and HLA-B/C Alterations and Correlations with Histopathologic Parameters and Disease-Free Survival}

Each tissue section contained stroma, endothelium, and lymphocytes (follicles), which served as an internal positive control for HLA-I expression. The stroma was positive for HLA-A (HCA2) and HLA-BC (HC-10) in $85 / 88$ and $88 / 88$ tumors, respectively. In 3/88 cases (3\%), HLA-A expression could not be detected in the tumor and stroma on repeated evaluations. HLA-A expression of tumors was normal in 27 of the remaining $85(32 \%)$ cases, while 48/85 (56\%) cases showed reduced expression and 10/85 cases (12\%) showed total loss of HLA-A (see Fig. 1 and Table 1). HLA-B/C expression was normal in 41/88 (47\%) cases, reduced in $41 / 88(47 \%)$ cases, and absent in $6 / 88$ (7\%) cases (see Table 1).

Correlations between HLA-A and -B/C expression and clinical and tumor parameters were investigated in univariate analysis. HLA-A down-regulation significantly correlated with a lower tumor stage $(p=0.005)$, less tumor recurrence $(p=0.03)$, and mucinous tumors $(p=0.05)$. HLA-B/C down-regulation significantly correlated with a lower tumor stage $(p<0.001$; Table 2).

Prognostic factors for disease-free survival (DFS) were investigated in univariate analysis. Tumor stage $(p=0.04)$, HLA-A expression ( $p=0.02)$, and HLA-B/C expression $(p=0.04)$ all significantly correlated with DFS (Figs. 2 and 3). None of the other clinical or histopathological parameters correlated with DFS (Table 1). Ten-year DFS was $47 \%$ in cases with normal HLA-A expression, $61 \%$ in cases with reduced HLA-A expression, and $100 \%$ in cases with absent HLA-A expression. For $\mathrm{HLA}-\mathrm{B} / \mathrm{C}$, these figures were $50 \%$ (normal HLA-B/C), 68\% (reduced HLA-B/C), and $100 \%$ (absent $H L A-B / C$ ), respectively. Multivariate analysis demonstrated that HLA-A expression was the only prognostic factor for DFS $(p=0.02$; relative risk $=2.0 ; 95 \%$ confidence interval: 1.1-3.6). The immunohistochemical results of the separate HLA-A and $\mathrm{HLA}-\mathrm{B} / \mathrm{C}$ analyses were combined to make these data comparable with other studies, which evaluated the expression of the entire HLA-ABC/ $\beta 2 \mathrm{~m}$ complex with W6/32. The first group $(n=24 ; 28 \%$ ) consisted of
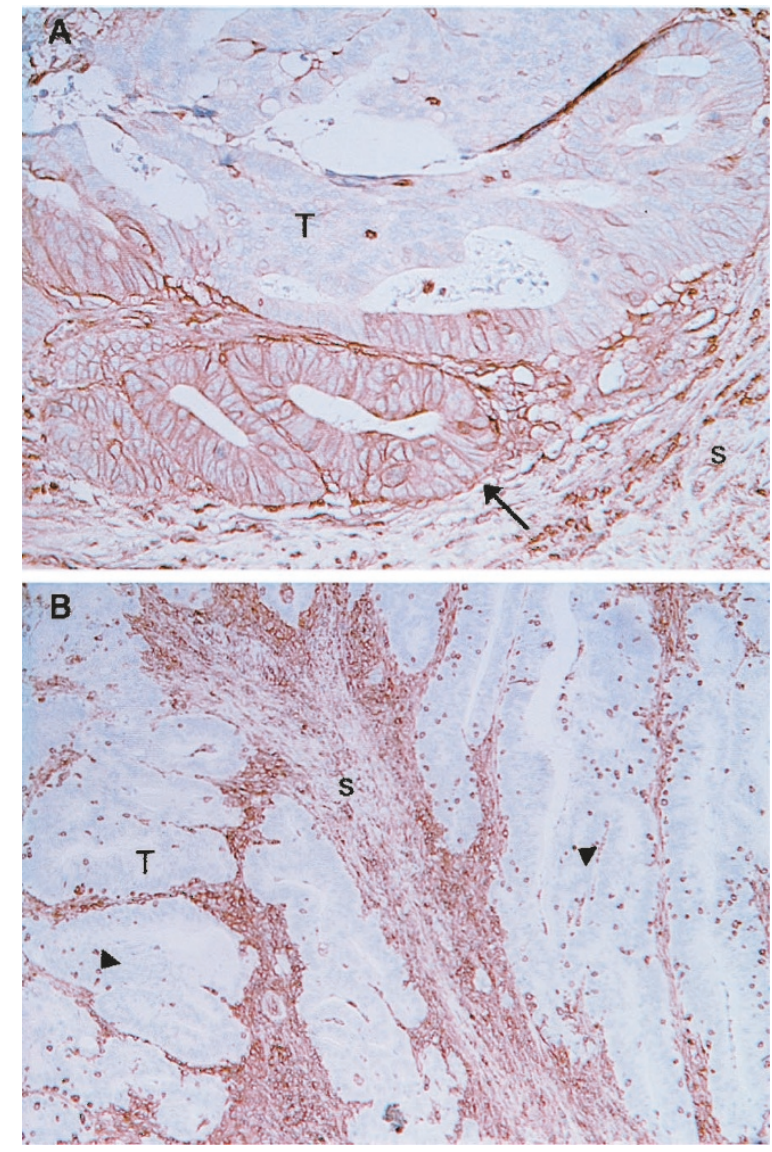

Figure 1.

(A) Heterogenous HLA expression in colorectal cancer. A colorectal carcinoma is stained for HLA-A as described in the Materials and Methods. A group of tumor cells is seen that expressed HLA-A in all cells (arrow). Within the same tumor, another group of tumor cells lost expression of HLA-A (T). Stroma also expressed HLA-A (s). (B) Loss of HLA expression by colorectal carcinoma cells. A tumor section is stained for HLA-A as described in the Materials and Methods section. All tumor cells lost HLA-A expression (T). Stroma $(s)$ and leukocytes infiltrating the tumor (arrowheads) were positive for HLA-A.

normal HLA-A and normal HLA-B/C expression in all tumor cells. The second group ( $n=55$; 65\%) demonstrated down-regulation of either HLA-A or HLA-B/C in some tumor cells. And finally, the third group $(n=6$; $7 \%$ ) consisted of patients with no HLA-A and no HLA-B/C expression on any tumor cell. There was no significant difference in DFS $(p=0.12$; Table 1) between these three groups. Although speculative, this might indicate that probably no significant differences in DFS would have been detected if these samples were analyzed using W6/32.

\section{Defects in Mismatch Repair Genes and $\beta 2$-Microglobulin in HLA-I-Negative Tumors}

Ten cases had total loss of HLA-A expression (Table 3). Of these, six cases demonstrated concomitant total loss of HLA-B/C expression. These six HLA-A $B C$-negative tumors did not recur during postoperative follow-up and may be a reflection of the good prognosis, as is seen in tumors with an MSI-high phenotype. We tested whether these cases were 
Table 1. Patient and Tumor Characteristics and Their Impact on Disease-Free Survival

\begin{tabular}{|c|c|c|c|}
\hline & $N(\%)$ & $\begin{array}{c}\text { Mean DFS } \\
\text { (years) }\end{array}$ & $p$ Value \\
\hline \multicolumn{4}{|l|}{ Gender } \\
\hline Male & $52(59)$ & 11.2 & \multirow[t]{2}{*}{0.23} \\
\hline Female & $36(41)$ & 12.3 & \\
\hline \multicolumn{4}{|l|}{ Age } \\
\hline$<50$ & $12(14)$ & 11.6 & \multirow[t]{2}{*}{0.82} \\
\hline$\geq 50$ & $76(86)$ & 12.2 & \\
\hline \multicolumn{4}{|l|}{ Location } \\
\hline Colon & $54(61)$ & 12.8 & \multirow[t]{2}{*}{0.51} \\
\hline Rectosigmoid & $34(39)$ & 10.2 & \\
\hline \multicolumn{4}{|l|}{ Tumor stage } \\
\hline Stage II & $38(43)$ & 12.8 & \multirow[t]{2}{*}{0.04} \\
\hline Stage III & $50(57)$ & 10.6 & \\
\hline \multicolumn{4}{|l|}{ Differentiation } \\
\hline Poor & $54(61)$ & 11.9 & \multirow{4}{*}{0.68} \\
\hline Moderate & $20(23)$ & 11.5 & \\
\hline Well & $11(13)$ & 13.1 & \\
\hline Unassessable & $3(3)$ & 6.2 & \\
\hline \multicolumn{4}{|c|}{ Mucinous characteristics } \\
\hline No & $61(69)$ & 11.3 & \multirow[t]{2}{*}{0.88} \\
\hline Yes & $27(31)$ & 11.9 & \\
\hline \multicolumn{4}{|l|}{ TIL } \\
\hline Poor & $32(36)$ & 12.2 & \multirow{3}{*}{0.24} \\
\hline Moderate & $45(51)$ & 10.8 & \\
\hline Marked & $11(13)$ & 13.6 & \\
\hline \multicolumn{4}{|l|}{ Recurrences } \\
\hline No & $58(66)$ & - & \multirow[t]{2}{*}{ - } \\
\hline Yes & $30(34)$ & - & \\
\hline \multicolumn{4}{|l|}{ HLA-A expression } \\
\hline Normal & $27(32)$ & 8.4 & \multirow{4}{*}{0.02} \\
\hline Reduced & $48(56)$ & 12.1 & \\
\hline Absent & $10(12)$ & * & \\
\hline Not evaluable & 3 & & \\
\hline \multicolumn{4}{|c|}{ HLA-B/C expression } \\
\hline Normal & $41(47)$ & 8.7 & \multirow{3}{*}{0.04} \\
\hline Reduced & $41(47)$ & 13.4 & \\
\hline Absent & $6(7)$ & * & \\
\hline \multicolumn{4}{|c|}{ HLA-ABC expression } \\
\hline Normal & $24(28)$ & 8.7 & \multirow{4}{*}{0.12} \\
\hline Reduced & $55(65)$ & 12.5 & \\
\hline Absent & $6(7)$ & * & \\
\hline Not evaluable & 3 & & \\
\hline
\end{tabular}

Patient and tumor characteristics of 88 curatively resected colorectal cancer patients. In addition, each parameter (except recurrences) was correlated to disease-free survival (DFS). Of these parameters, tumor stage, HLA-A, and $\mathrm{HLA}-\mathrm{B} / \mathrm{C}$ expression were significantly correlated with DFS. TIL $=$ tumorinfiltrating leucocytes; ${ }^{*}=$ no recurrences occurred; percentages are shown in parentheses.

mismatch repair deficient with secondary instability in repetitive sequences of exons 1 or 2 of the $\beta 2$ microglobulin gene. First, we tested MLH-1, MSH2, MSH6, and $\beta 2 \mathrm{~m}$ protein expression immunohistochemically. The six tumors were matched as much as possible for sex, age, tumor location, tumor stage, and mucinous characteristics with tumors from a group with normal HLA-A and HLA-B/C and a group with reduced HLA-A and reduced $\mathrm{HLA}-\mathrm{B} / \mathrm{C}$ expression (Table 3). MLH1 protein expression was lost in two of six cases (33\%) and doubtfully positive in another case of the HLA-A/ $\mathrm{BC}$-negative cases. In one of these MLH1-negative cases, MSH2 and MSH6 expression was also lost, bringing the total to three of six (50\%) HLA-I-negative cases demonstrating altered MMR protein expression. In contrast, MLH1 protein expression was lost or doubtfully positive in two of nine $(22 \%)$ controls only. The latter two cases showed reduced HLA-A and -B/C expression. There were no alterations in $\mathrm{MSH} 2$ and MSH6 protein expression in the control group. MSI analysis in the HLA-I-negative cases confirmed the mismatch repair deficiency in the three cases with loss of MLH1 expression and showed no MSI in the three other cases with normal MLH1 expression (Table 3). In addition, $\beta 2 \mathrm{~m}$ protein expression was lost in five of six HLA-I-negative cases, and one of six cases showed weak, focal $\beta 2 \mathrm{~m}$ expression in less than $5 \%$ of tumor cells. However, frameshift mutations in the repetitive sequences of exons 1 and 2 of the $\beta 2 \mathrm{~m}$ gene were not detected in any of these HLA-A/BC-negative cases, whereas it was detected in the concomitantly analyzed positive control.

\section{Discussion}

HLA-I expression on tumor cells is essential for T-cellmediated responses, which are deemed important for constraining tumor growth. In the present study, we showed that HLA-I down-regulation occurred in $72 \%$ of colorectal cancer patients and, surprisingly, correlated with a lower tumor stage and a better prognosis in multivariate analysis. In addition, tumors with total loss of HLA-I had the best prognosis, and $50 \%$ of these tumors were correlated with a MSI-high phenotype. Three cases were not evaluable for HLA-A expression because, in these cases, the internal positive control (stromal tissue) was found to be negative. These three cases were evaluable for HLA-B/C expression. A possible explanation might be that these patients have a HLA phenotype that is not recognized by HCA2. For instance, it is known that HLA-A24 is not recognized by HCA2 (Stam et al, 1990).

Our observed frequency of alterations in HLA-I is in agreement with other studies and suggests that our study cohort is comparable with other reported populations (Cordon et al, 1991; Durrant et al, 1987; Kaklamanis et al, 1992; Lopez-Nevot et al, 1989; Moller et al, 1991a, 1991b; Moore et al, 1986; Smith et al, 1989; Stein et al, 1988; van den Ingh et al, 1987). The improved prognosis for patients with tumors that had down-regulated HLA-I, and HLA-A in particular, is a novel finding and argues against the importance of T-cell-mediated immune surveillance. A possible explanation for our observations may be that natural killer (NK) cells were involved. NK cells make up for $15 \%$ of the lymphocytes in the systemic circulation and may clear HLA-I-negative tumor cells that attempt to metastasize into the systemic circulation and maybe even to regional lymph nodes, although not many NK cells are present in lymph nodes (Karre, 1995). Substantial evidence has accumulated that 
Table 2. Correlations Between HLA-I Expression and Clinical and Histopathological Parameters

\begin{tabular}{|c|c|c|c|c|c|c|c|c|}
\hline & \multicolumn{3}{|c|}{ HLA-A } & \multirow[b]{2}{*}{$p$ Value } & \multicolumn{3}{|c|}{$\mathrm{HLA}-\mathrm{B} / \mathrm{C}$} & \multirow[b]{2}{*}{$p$ Value } \\
\hline & Normal & Reduced & Absent & & Normal & Reduced & Absent & \\
\hline \multicolumn{9}{|l|}{ Sex } \\
\hline Male & 18 & 26 & 6 & \multirow[t]{2}{*}{0.57} & 23 & 25 & 4 & \multirow[t]{2}{*}{0.84} \\
\hline Female & 9 & 22 & 4 & & 18 & 16 & 2 & \\
\hline \multicolumn{9}{|l|}{ Age } \\
\hline$<50$ & 5 & 7 & & \multirow{2}{*}{0.35} & 5 & 7 & & \multirow{2}{*}{0.49} \\
\hline$>50$ & 22 & 41 & 10 & & 36 & 34 & 6 & \\
\hline \multicolumn{9}{|l|}{ Location } \\
\hline Colon & 16 & 30 & 7 & \multirow[t]{2}{*}{0.84} & 22 & 27 & 5 & \multirow[t]{2}{*}{0.27} \\
\hline Rectosigmoid & 11 & 18 & 3 & & 19 & 14 & 1 & \\
\hline \multicolumn{9}{|l|}{ Tumor stage } \\
\hline Stage II & 6 & 22 & 8 & \multirow[t]{2}{*}{0.005} & 8 & 25 & 5 & \multirow[t]{2}{*}{$<0.001$} \\
\hline Stage III & 21 & 26 & 2 & & 33 & 16 & 1 & \\
\hline \multicolumn{9}{|l|}{ Differentiation } \\
\hline Poor & 17 & 28 & 7 & \multirow{3}{*}{0.68} & 25 & 26 & 3 & \multirow{3}{*}{0.70} \\
\hline Moderate & 5 & 12 & 3 & & 9 & 8 & 3 & \\
\hline Well & 3 & 7 & & & 5 & 6 & & \\
\hline \multicolumn{9}{|l|}{ Mucinous } \\
\hline No & 15 & 38 & 5 & \multirow[t]{2}{*}{0.05} & 28 & 31 & 2 & \multirow[t]{2}{*}{0.11} \\
\hline Yes & 12 & 10 & 5 & & 13 & 10 & 4 & \\
\hline \multicolumn{9}{|l|}{ TILS } \\
\hline Poor & 9 & 18 & 4 & \multirow{3}{*}{0.47} & 14 & 15 & 3 & \multirow{3}{*}{0.93} \\
\hline Moderate & 17 & 23 & 4 & & 22 & 21 & 2 & \\
\hline Marked & 1 & 7 & 2 & & 5 & 5 & 1 & \\
\hline \multicolumn{9}{|l|}{ Recurrences } \\
\hline No & 14 & 31 & 10 & 0.03 & 23 & 29 & 6 & 0.07 \\
\hline Yes & 13 & 17 & & & 18 & 12 & & \\
\hline
\end{tabular}

Correlation between HLA-A and HLA-B/C expression and clinical and histopathological factors. HLA-A down-regulation was significantly correlated with a lower tumor stage, mucinous tumors, and fewer tumor recurrences. HLA-B/C expression was correlated to tumor stage only. Statistically significant correlations are in bold.

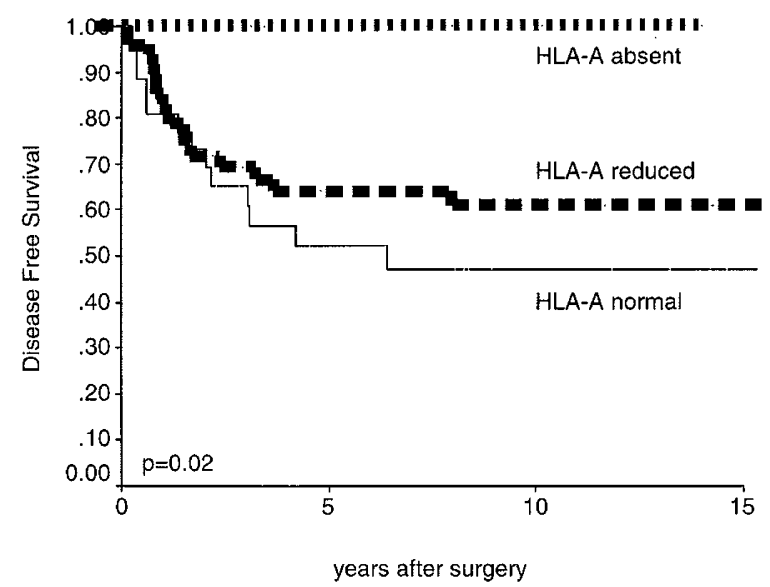

Figure 2.

Disease-free survival (DFS) was calculated using Kaplan-Meier methodology. Patients with tumors that had HLA-A expression on all tumor cells (HLA-A normal, $n=27$ ) had a 10 -year DFS of $47 \%$. Patients with tumors displaying heterogeneous HLA-A expression (as shown in Fig. 1A, depicted here as HLA-A reduced, $n=48$ ) had a 10 -year DFS of $61 \%$. Patients with tumors that had no HLA-A on the tumor cells (shown as HLA-A absent, $n=10$ ) did not develop a tumor recurrence during years of follow-up. The difference in DFS was statistically significant $(p=0.02)$.

supports the antitumor effects of NK cells in animal models (Barlozzari et al, 1985; Gorelik et al, 1982) and in humans (Coca et al, 1997; Riccardi et al, 1980;

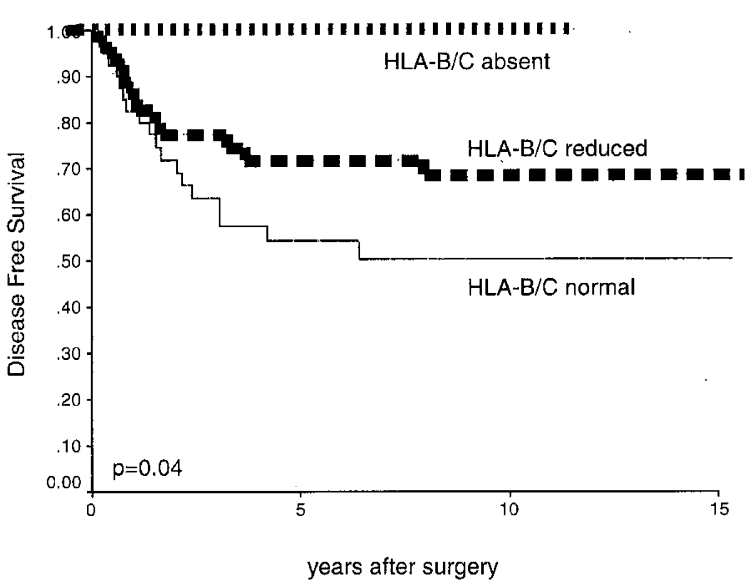

Figure 3.

Disease-free survival (DFS) was calculated using Kaplan-Meier methodology. Patients with tumors that had HLA-B/C expression on all tumor cells (HLA-B/C normal, $n=47$ ) had a 10 -year DFS of $50 \%$. Patients with tumors displaying heterogeneous HLA-B/C expression (as shown in Fig. 1A, depicted here as HLA-B/C reduced, $n=47$ ) had a 10 -year DFS of $68 \%$. Patients with tumors that had no HLA-B/C on the tumor cells (shown as HLA-B/C absent, $n=6$ ) did not develop a tumor recurrence during years of follow-up. The difference in DFS was statistically significant $(p=0.04)$.

Tartter et al, 1987; van Duinen et al, 1988; Whiteside and Herberman, 1994). For instance, Blom et al (1997) demonstrated that down-regulation of HLA-A expres- 
Table 3. Characteristics of HLA-A and HLA-B/C Negative Tumors and Matched Controls

\begin{tabular}{|c|c|c|c|c|c|c|c|c|c|c|c|c|c|c|}
\hline Case & Sex & Age & $H L A-A^{a}$ & $\mathrm{HLA}-\mathrm{BC}^{a}$ & $\begin{array}{l}\text { Tumor } \\
\text { Iocation }\end{array}$ & $\begin{array}{l}\text { Tumor } \\
\text { stage }\end{array}$ & $\begin{array}{l}\text { Mucinous } \\
\text { features }\end{array}$ & $\mathrm{p} 53^{b}$ & MLH1 & MSH2 & MSH6 & MSI & $\begin{array}{l}\beta 2 \mathrm{~m} \\
\mathrm{IHC}\end{array}$ & $\begin{array}{c}\text { Repeats in } \\
\beta 2 \mathrm{~m}\end{array}$ \\
\hline 23 & $\mathrm{~m}$ & 65.6 & 0 & 0 & $\mathrm{RS}$ & II & no & 60 & + & + & + & low & - & - \\
\hline 3 & $\mathrm{~m}$ & 72.0 & 1 & 1 & $\mathrm{R}$ & II & no & 20 & + & + & + & nt & $\mathrm{nt}$ & $\mathrm{nt}$ \\
\hline 159 & $f$ & 68.3 & 2 & 2 & $\mathrm{R}$ & II & no & 10 & + & + & + & $\mathrm{nt}$ & + & $\mathrm{nt}$ \\
\hline 50 & $\mathrm{~m}$ & 72.8 & 0 & 0 & CE & III & no & 0 & + & + & + & low & - & - \\
\hline 198 & $\mathrm{~m}$ & 79.1 & 1 & 1 & CE & III & no & 0 & + & + & + & $\mathrm{nt}$ & $\mathrm{nt}$ & $\mathrm{nt}$ \\
\hline 36 & $\mathrm{~m}$ & 73.3 & 2 & 2 & CA & III & no & 90 & + & + & + & $\mathrm{nt}$ & + & nt \\
\hline 139 & $\mathrm{~m}$ & 71.6 & 0 & 0 & CE & II & yes & 2 & $+1-$ & + & + & high & - & - \\
\hline 76 & $f$ & 65.5 & 1 & 1 & $\mathrm{CA}$ & II & yes & 0 & - & + & $\begin{array}{r}+ \\
(\mathrm{fp})\end{array}$ & nt & nt & $\mathrm{nt}$ \\
\hline 177 & m & 73.9 & 2 & 2 & S & II & yes & 0 & + & + & + & nt & nt & $\mathrm{nt}$ \\
\hline 145 & $f$ & 85.0 & 0 & 0 & CA & II & yes & 0 & - & + & + & high & $<5 \%$ & - \\
\hline 184 & $f$ & 80.0 & 1 & 1 & CE & II & yes & 0 & $+1-$ & + & + & nt & $\mathrm{nt}$ & $\mathrm{nt}$ \\
\hline 107 & $f$ & 79.6 & 2 & 2 & CE & II & yes & 70 & + & + & + & $\mathrm{nt}$ & nt & $\mathrm{nt}$ \\
\hline 157 & $f$ & 79.4 & 0 & 0 & CE & II & yes & 1 & - & - & - & high & - & - \\
\hline 194 & $\mathrm{~m}$ & 84.4 & 0 & 0 & CE & II & yes & 0 & + & + & + & low & - & - \\
\hline 37 & $\mathrm{~m}$ & 68.8 & 1 & 1 & $\mathrm{CA}$ & II & yes & 0 & + & + & + & $\mathrm{nt}$ & nt & $\mathrm{nt}$ \\
\hline 140 & $\mathrm{~m}$ & 74.3 & 0 & 1 & CE & II & yes & 20 & $\mathrm{nt}$ & $\mathrm{nt}$ & $\mathrm{nt}$ & nt & $\mathrm{nt}$ & $\mathrm{nt}$ \\
\hline 25 & $f$ & 80.7 & 0 & 1 & $\mathrm{R}$ & III & no & 90 & $\mathrm{nt}$ & nt & $\mathrm{nt}$ & $\mathrm{nt}$ & $\mathrm{nt}$ & $\mathrm{nt}$ \\
\hline 13 & $\mathrm{~m}$ & 64.1 & 0 & 1 & $S$ & II & no & 50 & $\mathrm{nt}$ & nt & $\mathrm{nt}$ & $\mathrm{nt}$ & $\mathrm{nt}$ & $\mathrm{nt}$ \\
\hline 165 & $f$ & 66.1 & 0 & 1 & $\mathrm{R}$ & II & no & 50 & nt & $\mathrm{nt}$ & nt & $\mathrm{nt}$ & $\mathrm{nt}$ & $\mathrm{nt}$ \\
\hline
\end{tabular}

$\mathrm{CA}=$ colon ascendens; $\mathrm{CE}=$ cecum; $\mathrm{f}=$ female; $\mathrm{f} p=$ focally positive; $\mathrm{m}=$ male; $\mathrm{nt}=$ not tested; $\mathrm{R}=$ rectum; $\mathrm{RS}=$ rectosigmoid $\mathrm{S}=$ sigmoid; $-=$ negative staining; $+=$ positive staining; $+/-=$ doubtfully positive.

${ }^{a}$ HLA expression: 0 = absent; 1 = reduced; 2 = normal.

${ }^{b}$ Percentage of tumor-positive nuclei are shown.

The characteristics of the six patients with HLA-A and HLA-B/C negative tumors (first line of each subsection) and nine matched controls (second and third lines of each subsection) are summarized. Age is presented in years and p53 overexpression was analyzed using D0-7 and by estimating the percentage of tumor-positive nuclei. MSI status was analyzed immunohistochemically and genetically using the markers recommended by the NCI (Boland et al, 1998). Expression of $\beta 2 \mathrm{~m}$ was analyzed immunohistochemically and mutations in repeating nucleotide sequences in exons 1 and 2 of the $\beta 2 \mathrm{~m}$ gene were analyzed.

sion was an independent prognostic factor associated with a better clinical outcome in a study using HCA2 and $\mathrm{HC}-10$ on 30 uveal melanomas. Like in colorectal cancer patients, the prognosis of uveal melanoma is mainly determined by hematogenous metastases to distant organs. Others have also correlated HLA-I expression in colorectal cancers to tumor stage and prognosis but did not find a correlation (Durrant et al, 1987; Moller et al, 1991a, 1991b; Stein et al, 1988). These studies differ from our study in several aspects. First, the follow-up in aforementioned studies is limited. The median follow-up in our study is more than 5 years. Second, the previously mentioned studies analyze expression of the entire HLA-ABC/ $\beta 2 \mathrm{~m}$ complex using W6/32. In contrast, we analyzed expression of the HLA-A and HLA-B/C locus separately and found that only HLA-A expression provided independent prognostic information for disease recurrence. Indirect support for the importance of analyzing subtle locusspecific losses was also seen in our study because, when we analyzed our patients by combining the results of the individual markers HCA2 (HLA-A) and $\mathrm{HC}-10$ (HLA-B/C) to make them comparable with evaluation of the expression of the entire HLA-ABC/ $\beta 2 \mathrm{~m}$ complex, we found no correlations between HLA-I expression and DFS in our patients. Recently, Feenstra et al (1999) showed that 26/84 head and neck squamous-cell carcinomas also had changes in HLA-A and/or -B/C expression, whereas no changes in HLA-I expression were observed when these cases were evaluated with $W 6 / 32$ or anti- $\beta 2 \mathrm{~m}$. Our data indicate that subtle locus-specific HLA defects provide prognostic information. This may be a reflection of NK cell activation by loss of specific HLA loci. Alternatively, the limited number of patients with loss of HLA B/C may preclude drawing valid conclusions regarding its prognostic significance.

Another explanation for the better prognosis associated with down-regulation of HLA-I may be a correlation with an "attenuated tumor aggressiveness," eg, as is observed in tumors with microsatellite instability (MSI) (Lothe et al, 1993). In this particular pathway, it has been reported that tumors sometimes lack HLA-I expression due to frameshift mutations in repetitive sequences of exons 1 and 2 of the $\beta 2 \mathrm{~m}$ gene (Bicknell et al, 1994; Bodmer et al, 1994; Momburg and Koch, 1989). Indeed, we found that $50 \%$ (3/6) of our HLA-Inegative cases had a MSI-high phenotype, but none 
of the tumors with total HLA-A/BC loss showed mutations in the repetitive sequences of exons 1 and 2 of $\beta 2 \mathrm{~m}$. This is a much higher proportion of MSI positivity than reported in the literature for sporadic colorectal cancer (Jass et al, 1998). In contrast, loss of MLH-1 was only found in $22 \%$ (2/9) of matched controls, which is in agreement with the reported frequency in sporadic colorectal cancer. In view of the age of the patients and location of the tumors, it was most likely that $\mathrm{MSI}$ was caused by hypermethylation of the MLH1-promotor region. Hypermethylation silences $\mathrm{MLH} 1$ expression and is frequently found with increasing age and in the proximal colon (Issa, 2000; Momparler and Bovenzi, 2000). A number of mechanisms other than $\beta 2 \mathrm{~m}$-expression defects are known that can account for down-regulation of HLA-I expression, such as genetic defects in the coding sequences of the HLA-I heavy chains (Jimenez et al, 1999; Koopman et al, 2000), regulatory defects (Browning et al, 1996), or defects in antigen processing and presentation, eg, in transporter associated with antigen processing. For instance, the latter were shown to account for a large proportion of HLA-I alterations in breast cancer (Kaklamanis et al, 1995), head and neck squamous cell carcinomas (Feenstra et al, 1999; Seliger et al, 1997), and $14 \%$ of colorectal carcinomas (Kaklamanis et al, 1994).

In conclusion, we report that locus-specific HLA-I down-regulation occurred in $72 \%$ of colorectal cancers and that HLA-A was an independent prognostic factor for a longer DFS. This applied in particular to a subgroup with total loss of HLA-I, which may be correlated with a MSI-high phenotype.

\section{Materials and Methods}

\section{Patients}

A random group of 88 colorectal cancer patients from a previously described cohort of curatively resected colorectal cancer patients (Tollenaar et al, 1998) was analyzed for HLA-I expression. Clinical information and histopathological information is shown in Table 1. Tumors were staged according to the American Joint Committee on Cancer (AJCC) criteria (Beahrs et al, 1992): $57 \%$ of cases were stage II primaries (equivalent to Dukes B) and 43\% were stage III (equivalent to Dukes C). The average age of the patients was 66.4 years (range: 26.9-85.0; SD: 12.5 years). Tumors were evaluated for differentiation grade, mucinous characteristics, and lymphocytic infiltration according to Jass' criteria (Jass et al, 1996) on hematoxylin-eosin stainings. Patient follow-up was completed until October 2000, with a median follow-up of 5.4 years (range: $0.1-18.6$ years, SD $=5.2$ years).

\section{Immunohistochemistry and Evaluation}

Tissue sections were stained using one of two monoclonal antibodies (culture supernatant) for HLA-I, kindly provided by Dr. J. J. Neefjes from the Netherlands Cancer Institute (Amsterdam, The Netherlands): HCA2 (1:100), which binds to HLA-A, and HC-10
(1:200), which preferentially binds to HLA-B/C (Stam et al, 1990). A polyclonal antibody against beta-2microglobulin ( $\beta 2 \mathrm{~m} ; 1: 10,000$; DAKO, Denmark) was used to assess $\beta 2 \mathrm{~m}$ protein expression in HLA-A- and HLA-B/C-negative cases.

Staining of mismatch repair proteins was performed with anti-MLH1 (1:50; Zymed Laboratories, San Francisco, California), anti-MSH2 (1:100; Calbiochem, Cambridge, United Kingdom), and anti-MSH6 (1:3000; Transduction Laboratories, Lexington, Kentucky). P53 stainings were used as previously described (Tollenaar et al, 1998). Four-micrometer-thick tissue sections were prepared on aminopropylethoxysilane (APES)-coated slides and dried overnight at $37^{\circ} \mathrm{C}$. Next, tissue sections were deparaffinized three times in xylene for a total of 15 minutes. Endogenous peroxidase was blocked in $0.03 \%$ hydrogen-peroxide methanol for 20 minutes and subsequently rehydrated. Antigen retrieval was done by boiling in $10 \mathrm{~mm}$ citrate buffer $(\mathrm{pH}=6.0)$ for 10 minutes using a microwave oven (HCA2, HC-10, MSH6, $\beta 2 \mathrm{~m}$ ) or in 1 mM EDTA (MLH1, MSH2), after which the sections were cooled in this buffer for at least 2 hours at room temperature. After rinsing in demi-water and phosphate-buffered saline (PBS), the tissue sections were incubated with the primary antibody diluted in $1 \%(\mathrm{w} / \mathrm{v}) \mathrm{PBS} /$ bovine serum albumin overnight at room temperature. Sections were washed in PBS and incubated with biotinylated rabbit-anti-mouse (1:200; DAKO, Glostrup, Denmark) for 30 minutes (for HCA2, $\mathrm{HC}-10$, and $\mathrm{MSH} 6)$ or with biotinylated swine-antirabbit (1:400; DAKO; for anti- $\beta 2 \mathrm{~m})$, washed again with PBS, and incubated with streptavidin-biotin complex (1:100, DAKO, Glostrup, Denmark) for 30 minutes. The other sections (MLH-1, MSH2) were incubated with EnVision peroxidase mouse system (DAKO) for 30 minutes. Sections were washed and developed in 3,3-di-amino-benzidine tetrahydrochloride substrate solution containing $0.002 \%$ hydrogen peroxide for 10 minutes. The sections were then counterstained with hematoxylin, dehydrated, cleared in xylene, and mounted with pertex.

Microscopic analysis was done separately by two observers who had no knowledge of the clinical outcome of the patients. The percentage of the tumor cells expressing HLA-A, HLA-B/C, and $\beta 2 m$ on the cell membrane was estimated in each case. In those cases in which the investigators disagreed, the slides were reviewed and a consensus was met. Normal HLA expression was defined as a situation in which all tumor cells expressed HLA. HLA expression was defined as reduced when some tumor cells showed HLA-A or $-B / C$ expression while others showed no expression. Total loss of HLA expression was noted when no tumor cells expressed HLA-A or -B/C and the internal control (tissue stroma, lymphocytes, and endothelium) expressed HLA expression. Tissue stroma and normal epithelium served as positive internal controls when analyzing MLH1, MSH2, and MSH6 expression. Expression of MLH1, MSH2, and MSH6 was scored as positive, negative, or doubtfully positive (ie, when the tumor nuclei vaguely expressed a 
signal while the internal control displayed normal staining intensity).

\section{DNA Isolation}

Genomic DNA of normal and tumor tissue was isolated from formalin-fixed paraffin-embedded material by taking tissue punches (diameter $0.6 \mu \mathrm{m}$ ) with a tissue microarrayer (Beecher) from tumor and normal areas selected on the basis of a hematoxylin- and eosin-stained slide. Using a Chelex extraction method, DNA was isolated from three punches, resuspended in $96 \mu$ l of PK-1 lysis buffer $(50 \mathrm{~mm} \mathrm{KCl,} 10 \mathrm{~mm}$ Tris [pH 8.3], $2.5 \mathrm{~mm} \mathrm{MgCl}_{2}, 0.45 \% \mathrm{NP}_{4} 0,0.45 \%$ Tween $20,0.1 \mathrm{mg} / \mathrm{ml}$ gelatin) containing $5 \%$ Chelex beads (Biorad, Hercules, California) and $5 \mu$ l of proteinase $\mathrm{K}(10 \mathrm{mg} / \mathrm{ml})$, and incubated for 12 hours at $56^{\circ} \mathrm{C}$. The suspension was incubated at $100^{\circ} \mathrm{C}$ for 10 minutes, centrifuged at 13,000 rpm for 10 minutes, and the supernatant carefully discarded.

\section{Microsatellite Instability Analysis}

Five markers, ie, two mononucleotide repeats (BAT25, BAT26) and three dinucleotide repeats (D2S123, D5S346, D17S250) recommended by the National Cancer Institute workshop on "Microsatellite Instability for Cancer Detection and Familial Predisposition," were used (Boland et al, 1998). Three additional mononucleotide repeat markers (BAT40, MSH3, and MSH6) were also evaluated. Of each the microsatellite marker sets of the reverse primer was tagged with a sequence of $7 \mathrm{bp}$ : 5'GTTTCTT3' on the 5' end. This modification was shown to significantly reduce falsepositive detection of MSI (de Leeuw et al, 2001). PCR was performed in a total reaction volume of $12 \mu \mathrm{l}$, containing $10 \mathrm{ng}$ of DNA, $1 \times$ AmpliTaq gold buffer (Applied Biosystems Inc., Foster City, California), 1\% bovine serum albumin (Roche Diagnostics), $2.0 \mathrm{~mm}$ $\mathrm{MgCl}_{2}, 200 \mu \mathrm{M}$ of each dNTP, $2.5 \cup$ AmpliTaq Gold polymerase (Applied Biosystems Inc.), 2 pmol of the primer pairs of the National Cancer Institute set and BAT 40, and 10 pmol of the primer pairs for $\mathrm{MSH} 2$ and MSH6 using the following conditions: 33 cycles of 1 minute at $96^{\circ} \mathrm{C}, 2$ minutes at $55^{\circ} \mathrm{C}, 1$ minute at $72^{\circ} \mathrm{C}$ in a Gene Amp 9700 thermocycler (Applied Biosystems Inc.). Hereafter, a final step of 7 minutes at $72^{\circ} \mathrm{C}$ was performed to ensure complete extension. Mixtures of $24 \mu \mathrm{l}$ deionized formamid, $1 \mu$ l TAMRA 500 size standard (Applied Biosystems Inc.), and $1.2 \mu \mathrm{l}$ of PCR product each were run on an $A B I 310$ Genetic Analyzer (Applied Biosystems Inc.) for 20 minutes with run profile GS STR POP $4(1.0 \mathrm{ml}) \mathrm{C}$ and analyzed with Gene Scan Analysis 3.1. Instability of a microsatellite marker is characterized by an alteration in the electrophoretic mobility of the PCR product of tumor DNA. This is facilitated by mixing the differently fluorescentlabeled PCR products from tumor and normal DNA in one tube and performing electrophoresis of the PCR products simultaneously in one capillary run. According to the established international criteria for MSI at the National Cancer Institute workshop, tumors were classified as (i) tumors with instability for two or more markers (MSI-high; MSI-H), (ii) tumors with instability for one marker (MSI-low; MSI-L), and (iii) no instability (MS-stable; MSS).

\section{Analysis of Repetitive Sequences in $\beta 2 m$ in HLA-I-Negative Cases}

Three areas of the $\beta 2 \mathrm{~m}$ gene containing repetitive sequences, 1 in exon 1 (an 8-bp CT repeat) and 2 in exon 2 (2 AAAAA repeats), were analyzed with modified primer sets as previously described (Bicknell et al, 1994). Primers were exon 1 forward: 5'AATATAAGTGGAGGCGGTCGC'3, reverse: 5'CAGAGCGGGAGGGTAGGA'3; exon 2 forward: 5'TCATCAATCCGACATTGAAGTTG'3, reverse: 5'GGCTGTGACAAAGTCACATGG'3. PCR was performed as described for microsatellite instability analysis (see previous section). A positive control containing a characterized mutation in the CT repeat of exon 1 of $\beta 2 \mathrm{~m}$ was also run in each experiment (kindly provided by K. Jordanova, Department of Pathology, Leiden University Medical Center, Leiden, The Netherlands).

\section{Statistical Analysis}

All statistical analyses were done using the SPSS software package (SPSS, Chicago, Illinois). The $\chi^{2}$ test for trend was used for comparing various clinicopathological parameters and $\mathrm{HCA} 2$ and $\mathrm{HC}-10$ expression. Kaplan-Meier analysis was used to calculate the disease-free survival. The log-rank test was used for comparison of the survival curves. Cox regression analysis was used for multivariate analysis and for univariate analysis of ordinal variables.

\section{Acknowledgements}

We are very grateful to Dr. J. Neefjes of the Netherlands Cancer Institute (Amsterdam, The Netherlands) for kindly providing the monocloncal antibodies $\mathrm{HCA} 2$ and HC-10. The technical assistance of Mrs. N. G. Ensink is also greatly appreciated.

\section{References}

Barlozzari T, Leonhardt J, Wiltrout RH, Herberman RB, and Reynolds CW (1985). Direct evidence for the role of LGL in the inhibition of experimental tumor metastases. J Immunol 134:2783-2789.

Barnstable CJ, Bodmer WF, Brown G, Galfre G, Milstein C, Williams AF, and Ziegler A (1978). Production of monoclonal antibodies to group A erythrocytes, HLA and other human cell surface antigens-New tools for genetic analysis. Cell 14:9-20.

Beahrs OH, Henson DE, Putter RPV, and Kennedy BJ, editors (1992). Manual for staging cancer. In: Manual for staging cancer, 4th ed. Philadelphia: J. B. Lippincott Company, 75-79.

Bernards R, Schrier PI, Houweling A, Bos JL, van der Eb AJ, Zijlstra M, and Melief CJ (1983). Tumorigenicity of cells transformed by adenovirus type 12 by evasion of T-cell immunity. Nature 305:776-779. 
Bicknell DC, Rowan A, and Bodmer WF (1994). Beta 2-microglobulin gene mutations: A study of established colorectal cell lines and fresh tumors. Proc Natl Acad Sci USA 91:4751-4756.

Blom DJ, Luyten GP, Mooy C, Kerkvliet S, Zwinderman AH, and Jager MJ (1997). Human leukocyte antigen class I expression. Marker of poor prognosis in uveal melanoma. Invest Ophthalmol Vis Sci 38:1865-1872.

Bodmer W, Bishop T, and Karran P (1994). Genetic steps in colorectal cancer. Nat Genet 6:217-219.

Boland CR, Thibodeau SN, Hamilton SR, Sidransky D, Eshleman JR, Burt RW, Meltzer SJ, Rodriguez-Bigas MA, Fodde R, Ranzani GN, and Srivastava S (1998). A National Cancer Institute workshop on microsatellite instability for cancer detection and familial predisposition: Development of international criteria for the determination of microsatellite instability in colorectal cancer. Cancer Res 58:5248-5257.

Bremers AJ and Parmiani G (1999). Immunotherapy for colon cancer. Lancet 353:1524-1525.

Browning M, Petronzelli F, Bicknell D, Krausa P, Rowan A, Tonks S, Murray N, Bodmer J, and Bodmer W (1996). Mechanisms of loss of HLA class I expression on colorectal tumor cells. Tissue Antigens 47:364-371.

Coca S, Perez PJ, Martinez D, Colmenarejo A, Saez MA, Vallejo C, Martos JA, and Moreno M (1997). The prognostic significance of intratumoral natural killer cells in patients with colorectal carcinoma. Cancer 79:2320-2328.

Concha A, Cabrera T, Ruiz CF, and Garrido F (1991). Can the HLA phenotype be used as a prognostic factor in breast carcinomas? Int J Cancer Suppl 6:146-154.

Cordon CC, Fuks Z, Drobnjak M, Moreno C, Eisenbach L, and Feldman M (1991). Expression of HLA-A, B, C antigens on primary and metastatic tumor cell populations of human carcinomas. Cancer Res 51:6372-6380.

de Leeuw WJ, van Puijenbroek M, Merx R, Wijnen JT, Brocker-Vriends AH, Tops C, Vasen H, Cornelisse CJ, and Morreau $\mathrm{H}$ (2001). Bias in detection of instability of the (C)8 mononucleotide repeat of MSH6 in tumours from HNPCC patients. Oncogene 20:6241-6244.

Durrant LG, Ballantyne KC, Armitage NC, Robins RA, Marksman R, Hardcastle JD, and Baldwin RW (1987). Quantitation of $\mathrm{MHC}$ antigen expression on colorectal tumours and its association with tumour progression. Br J Cancer 56:425432.

Esteban F, Redondo M, Delgado M, Garrido F, and Ruiz CF (1996). MHC class I antigens and tumour-infiltrating leucocytes in laryngeal cancer: Long-term follow-up. $\mathrm{Br} \mathrm{J}$ Cancer 74:1801-1804.

Feenstra M, Rozemuller E, Duran K, Stuy I, van den TJ, Slootweg $P$, de Weger R, and Tilanus M (1999). Mutation in the beta $2 \mathrm{~m}$ gene is not a frequent event in head and neck squamous cell carcinomas. Hum Immunol 60:697-706.

Garrido F, Cabrera T, Concha A, Glew S, Ruiz CF, and Stern PL (1993). Natural history of HLA expression during tumour development. Immunol Today 14:491-499.

Gorelik E, Wiltrout RH, Okumura K, Habu S, and Herberman RB (1982). Role of NK cells in the control of metastatic spread and growth of tumor cells in mice. Int $\mathrm{J}$ Cancer 30:107-112.
Greenlee RT, Murray T, Bolden S, and Wingo PA (2000). Cancer statistics, 2000. CA Cancer J Clin 50:7-33.

Issa JP (2000). The epigenetics of colorectal cancer. Ann NY Acad Sci 910:140-153.

Jass JR, Ajioka Y, Allen JP, Chan YF, Cohen RJ, Nixon JM, Radojkovic M, Restall AP, Stables SR, and Zwi LJ (1996). Assessment of invasive growth pattern and lymphocytic infiltration in colorectal cancer. Histopathology 28:543-548.

Jass JR, Do KA, Simms LA, lino H, Wynter C, Pillay SP, Searle J, Radford-Smith G, Young J, and Leggett B (1998). Morphology of sporadic colorectal cancer with DNA replication errors. Gut 42:673-679.

Jimenez P, Canton J, Collado A, Cabrera T, Serrano A, Real LM, Garcia A, Ruiz-Cabello F, and Garrido F (1999). Chromosome loss is the most frequent mechanism contributing to HLA haplotype loss in human tumors. Int J Cancer 83:91-97.

Kaklamanis L, Gatter KC, Hill AB, Mortensen N, Harris AL, Krausa P, McMichael A, Bodmer JG, and Bodmer WF (1992). Loss of HLA class-I alleles, heavy chains and beta 2-microglobulin in colorectal cancer. Int $\mathrm{J}$ Cancer 51:379385.

Kaklamanis L, Leek R, Koukourakis M, Gatter KC, and Harris AL (1995). Loss of transporter in antigen processing 1 transport protein and major histocompatibility complex class I molecules in metastatic versus primary breast cancer. Cancer Res 55:5191-5194.

Kaklamanis L, Townsend A, Doussis-Anagnostopoulou IA, Mortensen N, Harris AL, and Gatter KC (1994). Loss of major histocompatibility complex-encoded transporter associated with antigen presentation (TAP) in colorectal cancer. Am J Pathol 145:505-509.

Karre K (1995). Express yourself or die: Peptides, MHC molecules, and NK cells. Science 267:978-979.

Koopman LA, Corver WE, van der Slik AR, Giphart MJ, and Fleuren GJ (2000). Multiple genetic alterations cause frequent and heterogeneous human histocompatibility leukocyte antigen class I loss in cervical cancer. J Exp Med 191:961-976.

Lopez-Nevot MA, Esteban F, Ferron A, Gutierrez J, Oliva MR, Romero C, Huelin C, Ruiz CF, and Garrido F (1989). HLA class I gene expression on human primary tumours and autologous metastases: Demonstration of selective losses of HLA antigens on colorectal, gastric and laryngeal carcinomas. Br J Cancer 59:221-226.

Lothe RA, Peltomaki P, Meling GI, Aaltonen LA, Nystrom LM, Pylkkanen L, Heimdal K, Andersen TI, Moller P, and Rognum TO (1993). Genomic instability in colorectal cancer: Relationship to clinicopathological variables and family history. Cancer Res 53:5849-5852.

Moller P, Koretz K, Schlag P, and Momburg F (1991a). Frequency of abnormal expression of HLA-A, B, C and HLA-DR molecules, invariant chain, and LFA-3 (CD58) in colorectal carcinoma and its impact on tumor recurrence. Int J Cancer Suppl 6:155-162.

Moller P, Momburg F, Koretz K, Moldenhauer G, Herfarth C, Otto HF, Hammerling GJ, and Schlag P (1991b). Influence of major histocompatibility complex class I and II antigens on survival in colorectal carcinoma. Cancer Res 51:729-736.

Momburg F, Degener T, Bacchus E, Moldenhauer G, Hammerling GJ, and Moller P (1986). Loss of HLA-A, B, C and de novo expression of HLA-D in colorectal cancer. Int $\mathrm{J}$ Cancer 37:179-184. 
Momburg $F$ and Koch S (1989). Selective loss of beta 2-microglobulin mRNA in human colon carcinoma. J Exp Med 169:309-314.

Momparler RL and Bovenzi V (2000). DNA methylation and cancer. J Cell Physiol 183:145-154.

Moore M, Ghosh AK, Johnston D, and Street AJ (1986). Expression of MHC class II products on human colorectal cancer. An immunohistological and flow cytometric study. J Immunogenet 13:201-209.

Riccardi C, Santoni A, Barlozzari T, Puccetti P, and Herberman RB (1980). In vivo natural reactivity of mice against tumor cells. Int J Cancer 25:475-486.

Seliger B, Maeurer MJ, and Ferrone S (1997). TAP offTumors on. Immunol Today 18:292-299.

Smith ME, Marsh SG, Bodmer JG, Gelsthorpe K, and Bodmer WF (1989). Loss of HLA-A, B, C allele products and lymphocyte function-associated antigen 3 in colorectal neoplasia. Proc Natl Acad Sci U S A 86:5557-5561.

Stam NJ, Vroom TM, Peters PJ, Pastoors EB, and Ploegh HL (1990). HLA-A- and HLA-B-specific monoclonal antibodies reactive with free heavy chains in western blots, in formalinfixed, paraffin-embedded tissue sections and in cryoimmuno-electron microscopy. Int Immunol 2:113-125.

Stein B, Momburg F, Schwarz V, Schlag P, Moldenhauer G, and Moller P (1988). Reduction or loss of HLA-A, B, C antigens in colorectal carcinoma appears not to influence survival. Br J Cancer 57:364-368.

Tartter PI, Steinberg B, Barron DM, and Martinelli G (1987). The prognostic significance of natural killer cytotoxicity in patients with colorectal cancer. Arch Surg 122:1264-1268.
Tollenaar RA, van Krieken JH, van Slooten HJ, Bruinvels DJ, Nelemans KM, van den Broek LJ, Hermans J, and van Dierendonck JH (1998). Immunohistochemical detection of p53 and $\mathrm{Bcl}-2$ in colorectal carcinoma: No evidence for prognostic significance. Br J Cancer 77:1842-1847.

Tsioulias GJ, Triadafilopoulos G, Goldin E, Papavassiliou ED, Rizos S, Bassioukas P, and Rigas B (1993). Expression of HLA class I antigens in sporadic adenomas and histologically normal mucosa of the colon. Cancer Res 53:2374-2378.

van den Ingh HF, Ruiter DJ, Griffioen G, van Muijen GN, and Ferrone S (1987). HLA antigens in colorectal tumours-Low expression of HLA class I antigens in mucinous colorectal carcinomas. Br J Cancer 55:125-130.

van Duinen SG, Ruiter DJ, Broecker EB, van der Velde EA, Sorg C, Welvaart K, and Ferrone S (1988). Level of HLA antigens in locoregional metastases and clinical course of the disease in patients with melanoma. Cancer Res 48:10191025.

Wallich R, Bulbuc N, Hammerling GJ, Katzav S, Segal S, and Feldman M (1985). Abrogation of metastatic properties of tumour cells by de novo expression of $\mathrm{H}-2 \mathrm{~K}$ antigens following $\mathrm{H}-2$ gene transfection. Nature 315:301-305.

Whiteside TL and Herberman RB (1994). Role of human natural killer cells in health and disease. Clin Diagn Lab Immunol 1:125-133. 